\title{
Living at its dry limits: Tillandsiales in the Atacama Desert
}

\author{
Marcus A. Koch ${ }^{1,2} \cdot$ Dietmar Quandt $^{3} \cdot$ Alexander Siegmund $^{2,4}$
}

Received: 10 January 2022 / Accepted: 10 January 2022 / Published online: 7 February 2022

(c) The Author(s) 2022

The northern Chilean Atacama Desert is among those regions on Earth where life exists at its dry limits. There is almost zero rainfall or partly less than $1 \mathrm{~mm} /$ year in its core zone and the only source of water is a spatio-temporally complex fog system along the Pacific coast, which is reaching far into the hyperarid mainland. Hardly any vascular plants do grow in these areas, and thus, it is intriguing to be faced with a vegetation type built up by one single and highly specialized bromeliad species, Tillandsia landbeckii-also called Tillandsia lomas.

In recent decades, the Chilean-Peruvian fog ecosystems have shown increasing signs of decline, which might be linked to abrupt mesoscale climate shifts since the mid1970s (Schulz et al. 2012) and indicating severe (negative) population dynamics. However, the magnitude of the decline and the underlying ecologic-atmospheric relationships causing it are yet to be investigated (Latorre et al. 2011). Reports are alarming and indicate high mortality of Tillandsia within the coastal lomas, but currently the extent and quality of the die-back as well as the effects of the changing fog system on the degradation of the lomas are not understood (Cereceda et al. 2008).

Tillandsia landbeckii is often forming regular linear structures in a sloped desert landscape. Since the species lacks a typical root system, it generally depends on sloped

Contribution to "Living at its dry limits - Tillandsiales in the Atacama Desert".

Marcus A. Koch

marcus.koch@cos.uni-heidelberg.de

1 Centre for Organismal Studies, Heidelberg University, 69120 Heidelberg, Germany

2 Heidelberg Center for the Environment (HCE), Heidelberg University, Heidelberg, Germany

3 Nees-Institute for Biodiversity of Plants (NEES), University of Bonn, 53115 Bonn, Germany

4 Department of Geography - Research Group for Earth Observation (rgeo), Heidelberg University of Education, 69115 Heidelberg, Germany dunes (coppice dunes) to stabilize plant growth. Lacking a system of water uptake via root, these "grey tillandsias" harvest water with highly specialized trichomes utilizing incoming fog during the night and using obligately CAM photosynthesis (Haslam et al. 2003). Linear or banded pattern formation of vegetation in arid climates has been analysed in the past, but is still not understood in detail (Deblauwe et al. 2012). No biologically relevant data have been gathered, yet. In principal, substantial genetic variation in $T$. landbeckii populations, which may be essential to survive in a hyperarid environment for thousands of years (Latorre et al. 2011), can be maintained by different strategies: either a large number of genotypes is propagated clonally, or gene flow via pollen and subsequent seed dispersal is maintained and continuously creates genetic diversity (Merklinger et al. 2020). The formation of regular linear banding patterns might favor the hypothesis of clonal population growth, whereas the extreme habitats within the entire distribution range may require continuous local adaptation, which is dependent on gene flow and sexual reproduction. Various research groups have started to elaborate on factors being correlated with Tillandsia growth, vegetation patterning and fitness, but the interaction of biotic and abiotic factors have to be studied in detail (e.g., fog occurrence and dynamics, sand dune movement and characteristics, including grain size and structure, nitrogen fixation and cycling, vegetation turnover and dating).

The present topical collection of Plant Systematics and Evolution arose from a joint research consortium of Chilean, Peruvian, Spanish and German biologists, physical geographers and climatologists teamed up to lay the basis for a deeper understanding of Tillandsia fog oasis (Tillandsia lomas or Tillandsials) in arid and hyperarid desert areas of Chile and Peru. The research framework was funded by the European Union within the ERANet-LAC program from 2017 to 2020 ("The Chilean-Peruvian arid coastal fog ecosystems under climate change: understanding BiosphereAtmosphere interactions to support biodiversity conservation"). Various subprojects are also connected with the projects of the Collaborative Research Centre CRC1211 (Earth-evolution at the dry limit) funded by German 
Research Foundation (DFG), which is at the moment running with the second funding period (2020-2024). The edition of manuscripts for this topic collection was launched and discussed during the final symposium of the ERANetLAC program at Alto Patache, Atacama Desert Centre, organized by Centro UC Desierto de Atacama (Pontificia Universidad Católica de Chile, Santiago, Chile) in November 2019 and also invited contribution and participitation of members of CRC 1211. The central theme of this symposium was to discuss the most recent advances of transdisciplinary research contributing to our understanding of the biology, evolution, and biotic and abiotic interaction of Chilean-Peruvian Tillandsiales. Besides this primarily scientific value, the interdisciplinary research aims to raise awareness for the vulnerable and wordwide unique ecosystems built up by arenic Tillandsia species in Chile and Peru.

The eight most recent contributions presented therein, focused on epiarenic Tillandsia distribution and ecological niches (Villasante et al. 2021), T. landbeckii evolutionary history and timing of its origin (Möbus et al. 2021), Tillandsia population genetics and population biology and dynamics (Koch et al. 2019), spatial distribution of leaf wax composition of $T$. landbeckii across a large transect (Contreras et al. 2022), microbial diversity of sand-soil systems in Tillandsiales (Alfaro et al. 2021), climate and cloud dynamics in the Atacama Desert (García et al. 2021) and Atacama coastal fog dynamics (Del Río et al. 2021).

Further reading of related contributions published earlier in Plant Systematics and Evolution also adds to various aspects of Tillandsia ecology, systematics and evolution in the Atacama Desert: Till and Vitek (1985) described the new species T. marconae, and Rundel and Dillon (1998) presented first ecological insights into loma formations of coastal Chile and Peru. Donadío et al. (2015) provided a comprehensive morphological dataset for many Tillandsia species including T. landbeckii, and Koch et al. (2013) launched a biodiversity knowledge database providing many detailed records and field information on various epiarenic Tillandsias.

The evolutionary timeline of $T$. landbeckii, the most prominent epiarenic Tillandsia species in the Chilean Atacama Desert, is presented by Möbus et al. (2021). The onset of the diversification of the species is set into the Pleistocene at about 500,000 years ago, but also first evidence is provided for past reticulate gene flow involving other species, such as T. purpurea, which gave rise, for example, to T. marconae (Till and Vitek 1985).

Tillandsia purpurea is the vicariant arenic species from the Peruvian Sechura Desert. The ecological niche of this threatened species is characterized by Villasante et al. (2021). It is of particular importance that with the overlap of Peruvian-Chilean border distribution areas of T. landbeckii and T. purpurea, future comparative bio- and phylogeographic evidence might help to understand range dynamics of respective arid and hyperarid desert ecosystems, which may have also promoted biological diversification.

The complex ecological genetics have been explored by Koch et al. (2019) studying fine-scale and linearly structured genetic diversity and correlation with fitness parameters such as flowering frequency. Evidence is provided for a complex mixture of vegetative and sexual reproduction, contributing in concert to long-term population viability.

Leaf waxes are essential for Tillandsia to survive under arid and hyperarid conditions. This important trait has been studied by Contreras et al. (2022) showing that variation in leaf wax distribution and abundance relates to geographical characteristics and moisture sources and therefore might allow to trace past climate changes related to moisture changes along the Atacama Desert.

Although there is no obviously rich biodiversity interacting with T. landbeckii, Alfaro et al. (2021) showed that soil bacterial abundance, richness and diversity is significantly higher beneath $T$. landbeckii plants relative to bare soil indicating the significant biotic interactions framing a complex ecological interplay. Interestingly, there were no differences of soil bacteria composition found across altitudinal cline that also reflect clines in water supply due to fog events.

Among the various factors threatening Tillandsiales in Chile, changes in fog and low cloud occurrence and fog interannual variability are assumed to play a major role in the metapopulation decline. Del Rio et al. (2021) studied these effects in the context of global climate change, including El Niño Southern Oscillation (ENSO) and Interdecadal Pacific Oscillation (IPO), and its significant impact on interannual and decadal variability of fog and low cloud presence.

These coastal low-cloud dynamics in the hyperarid Atacama Fog Desert have been studied in further detail by García et al (2021). One main implication from this study is that fog presence and fog-water yields tend to be negatively related with both distance to the coast and elevation. Long-lasting fog events in Tillandsiales are thought to be the main source of water for the Tillandsia ecosystems and relate their geographic distribution to the lowest fog-water yields recorded. It is concluded that future climate trends may leave fog-dependent Tillandsia even less exposed to the already infrequent fog events resulting in further rapid vegetation decline.

In summary this topic collection not only shed light on a fascinating ecosystem existing at its dry limits, but it also provides a focus where the global climate change is threatening the entire biological system and thereby might exterminate some unique life on earth. 
The Editors would like to thank Barbora Šingliarová and Katarína Skokanová from the PSE Editorial office for their excellent editorial assistance.

Funding Open Access funding enabled and organized by Projekt DEAL.

Open Access This article is licensed under a Creative Commons Attribution 4.0 International License, which permits use, sharing, adaptation, distribution and reproduction in any medium or format, as long as you give appropriate credit to the original author(s) and the source, provide a link to the Creative Commons licence, and indicate if changes were made. The images or other third party material in this article are included in the article's Creative Commons licence, unless indicated otherwise in a credit line to the material. If material is not included in the article's Creative Commons licence and your intended use is not permitted by statutory regulation or exceeds the permitted use, you will need to obtain permission directly from the copyright holder. To view a copy of this licence, visit http://creativecommons.org/licenses/by/4.0/.

\section{References}

Alfaro FD, Manzano M, Almiray C, García JL, Osses P, Del Rio C, Vargas C, Latorre C, Koch MA, Siegmund A, Abades S (2021) Soil bacterial community structure of fog-dependent Tillandsia landbeckii dunes in the Atacama Desert. P1 Syst Evol 307:56. https://doi.org/10.1007/s00606-021-01781-0

Cereceda P, Larrain H, Osses P, Farías M, Egaña I (2008) The climate of the coast and fog zone in the Atacama Desert of Tarapacá Region, Chile. Atmos Res 87:301-311

Contreras S, Landahur M, García K, Latorre C, Reyers M, Rethemeyer J, Jaeschke A (2022) Leaf wax composition and distribution of Tillandsia landbeckii reflects moisture gradient across the hyperarid Atacama Desert. P1 Syst Evol 308:8. https://doi.org/10.1007/ s00606-021-01800-0

Deblauwe V, Couteron P, Bogaert J, Barbier N (2012) Determinants and dynamics of banded pattern migration in arid climates. Ecol Monogr 82:3-21. https://doi.org/10.1890/11-0362.1

Del Rio C, Lobos-Roco F, Latorre C, Koch MA, García JL, Osses P, Lambert F, Alfaro F, Siegmund A (2021) Spatial distribution and interannual variability of coastal fog and low clouds cover in the hyperarid Atacama Desert and implications for past and present Tillandsia landbeckii ecosystems. Pl Syst Evol 307:58. https://doi. org/10.1007/s00606-021-01782-z

Donadío S, Pozner R, Giussani LM (2015) Phylogenetic relationships within Tillandsia subgenus Diaphoranthema (Bromeliaceae, Tillandsioideae) based on a comprehensive morphological dataset. P1 Syst Evol 301:387-410. https://doi.org/10.1007/ s00606-014-1081-1
García JL, Lobos-Roco F, Schween JH, Del Rio C, Osses P, Vives R, Pezoa M, Siegmund A, Latorre C, Alfaro F, Koch MA, Loehnert U (2021) Climate and coastal low-cloud dynamic in the hyperarid Atacama fog Desert and the geographic distribution of Tillandsia landbeckii (Bromeliaceae) dune ecosystems. Pl Syst Evol 307:57. https://doi.org/10.1007/s00606-021-01775-y

Haslam R, Borland A, Maxwell K, Griffiths H (2003) Physiological responses of the CAM epiphyte Tillandsia usneoides L. (Bromeliaceae) to variations in light and water supply. J Pl Physiol 160:627-634. https://doi.org/10.1078/0176-1617-00970

Koch MA, Kleinpeter D, Auer E, Siegmund A, del Rio C, Osses P, García J-L, Marzol MV, Zizka G, Kiefer C (2019) Living at the dry limits: ecological genetics of Tillandsia landbeckii lomas in the Chilean Atacama Desert. Pl Syst Evol 305:1041-1053. https:// doi.org/10.1007/s00606-019-01623-0

Koch MA, Schröder CN, Kiefer M, Sack P (2013) A treasure trove of plant biodiversity from the 20th century: the Werner Rauh Heritage Project at Heidelberg Botanical Garden and Herbarium. Pl Syst Evol 299:1793-1800. https://doi.org/10.1007/ s00606-013-0835-5

Latorre C, Gonzáles AL, Quade J, Farina JM, Pinto R, Marquet PA (2011) Establishment and formation of fog-dependent Tillandsia landbeckii dunes in the Atacama Desert: evidence from radiocarbon and stable isotopes. J Geophys Res 116:G03033. https://doi. org/10.1029/2010JG001521

Merklinger FF, Zheng Y, Luebert F, Harpke D, Böhnert T, Stoll A, Koch MA, Blattner FR, Wiehe T, Quandt D (2020) Population genomics of Tillandsia landbeckii reveals unbalanced genetic diversity and founder effects in the Atacama Desert. Global Planet Change 184:103076. https://doi.org/10.1016/j.gloplacha. 2019.103076

Möbus J, Kiefer C, Quandt D, Barfuss MH, Koch MA (2021) Setting the evolutionary timeline: Tillandsia landbeckii in the Chilean Atacama Desert. Pl Syst Evol 307:39. https://doi.org/10.1007/ s00606-021-01760-5

Rundel PW, Dillon MO (1998) Ecological patterns in the Bromeliaceae of the lomas formation of coastal Chile and Peru. Pl Syst Evol 212:261-278. https://doi.org/10.1007/BF01089742

Schulz N, Boisier J, Aceituno P (2012) Climate change along the arid coast of northern Chile. Int J Climatol 32:1803-1814. https://doi. org/10.1002/joc. 2395

Till W, Vitel E (1985) Tillandsia marconae-eine neue Art aus der peruanischen Küstenwüste. Pl Syst Evol 149:143-147

Villasante Benavides F, Pauca-Tanco GA, Luque-Fernández CR, Del Pilar Quispe-Turpo J, Villegas Paredes LN, Siegmund A, Koch MA (2021) Distribution patterns, ecological niche and conservation status of endemic Tillandsia purpurea along the Peruvian coast. Pl Syst Evol 307:52. https://doi.org/10.1007/ s00606-021-01773-0

Publisher's Note Springer Nature remains neutral with regard to jurisdictional claims in published maps and institutional affiliations. 